\title{
LA CONSOLIDACIÓN DEL \\ CLERO SECULAR Y LA RECEPCIÓN \\ DEL CATOLICISMO TRIDENTINO, \\ 1600-1654
}

Juan Fernando Cobo Betancourt

En la primera mitad del siglo XVII, a través de las políticas de varios arzobispos reformistas, el catolicismo tridentino transformó radicalmente a la Iglesia y su proyecto evangelizador. Un aspecto de esta transformación fue institucional. Así, en este periodo se destacan el establecimiento de un seminario diocesano; la adopción y establecimiento de legislación eclesiástica sofisticada -primero en el sínodo provincial de 1606 y luego en el Primer Concilio Provincial de Santafé de 1625-; el crecimiento en número, educación y preparación del clero secular; y la aplicación de mecanismos disciplinarios sistemáticos para regular la aplicación y dirección del proyecto evangelizador, a través de visitas pastorales, exámenes y directrices que buscan la homogeneidad, normatividad y uniformidad del gobierno eclesiástico. Por otra parte, la transformación es ideológica. Las nuevas estrategias de evangelización responden a nuevas

\author{
JUAN Fernando CoBO BeTaNCOURT
}

prioridades tridentinas, que hacen énfasis en el valor de prácticas devocionales cotidianas y en el frecuente acceso a los sacramentos de la Iglesia.

En noviembre de 1636, el arzobispo Cristóbal de Torres (1635-1654) promulgó un decreto extraordinario. Eran instrucciones para eliminar "el abuso tan pernicioso que está entablado en las Indias, [y] principalmente en este Reino". No se trataba de la pobre conducta de los encomenderos u otros españoles frente a la población indígena, o la insuficiente educación del clero. Ni siquiera de la supervivencia de prácticas de origen aparentemente precolombino entre los naturales que tanto había obsesionado a sus predecesores, y que seguía generando preocupaciones a algunas autoridades. No, era "el hacer juicio y dar sentencia tan a carga cerrada contra una nación", refiriéndose a los indígenas, "sin haber precedido examen ni averiguación de los méritos y capacidad de cada uno". 
Y el resultado había sido considerarlos "totalmente incapaces de la sagrada comunión, y priva[r] a Cristianos de tan dóciles naturales del mayor bien que Dios dejó en su Iglesia, que es el Santísimo Sacramento” (AGI SF 227, núm. 17, 1v).

En los primeros ańos de la evangelización el Arzobispo reconoció que "había congruencias bastantes para ir poco a poco los prelados en esta materia" (1v). Pero ahora, continuaba el decreto, que "ya la larga experiencia ha mostrado con el buen suceso que en algunas partes se ha visto cuan conveniente es que todos los indios capaces comulguen" (1v). Esto no era una cuestión de justicia, o de procedimiento: era una necesidad práctica. Citando a Clemente VIII, Torres dejó su posición en claro: "estos indios no acabarían del todo de ser cristianos si les negaban la sagrada comunión” (1v). La idea que tenía Torres del papel y acción del sacramento de la Eucaristía en la evangelización era muy distinta a la de muchos de sus predecesores. De hecho, los autores del Sínodo Diocesano de 1556 y otros después de ellos, habían resuelto no admitir a la población indígena a la comunión por motivos de ortodoxia, no considerándolos dignos o preparados para recibir el sacramento ${ }^{1}$.

Pero para Torres el efecto era el contrario: "el demonio que tan fuerte se ha hecho y con posesión tan antigua ha estado encastillado en esta tierra", estaba utilizando incluso a los "católicos y píos" para excluir a la población indígena del sacramento central de la Iglesia tridentina (1v). Ahora, todos los sacerdotes activos en el Nuevo Reino debían enseñar no solo las cuatro oraciones básicas, los mandamientos y los misterios de la fe católica, sino además hacer un énfasis especial sobre la presencia de Cristo en el Santísimo Sacramento, y en animar a la población indígena a que frecuentara los sacramentos de la Penitencia y la Eucaristía. Finalmente, decretó un ultimátum para que todos los doctrineros, regulares o seculares, "dentro de seis meses [...] acaben de aprender la lengua de sus pueblos" (2r), para que con la predicación en lenguas indígenas pudieran "arrancar de raíz la idolatría y extirpar los vicios ordinarios de borracheras y amancebamiento" (3r). Advirtió además que estas instrucciones serían de ahora en adelante "el punto más sustancial" que se investigaría en las visitas pastorales. Y estas instrucciones debían explicárseles a los indios mismos, en sus lenguas, y copias de ellas debían ser exhibidas en la iglesia de cada doctrina. Nadie podría pretender ignorancia.

Este capítulo explora la transformación que experimentó la Iglesia del Nuevo Reino de Granada en la primera mitad del siglo XVII, la cual hizo posible que

${ }^{1}$ Como rezaban las Constituciones Sinodales de 1556 (p. 480): "el [sacramento] de la Eucaristía mandamos al presente que en ninguna manera se les administre [a los indios]”. 
un arzobispo de Santafé pudiera emitir un decreto de este tipo y con dicho contenido. Esto fue, en un nivel básico, un cambio institucional al interior de la Iglesia y su jefatura, hecho posible por varias circunstancias internas y externas. Cuando el arzobispo Torres promulgó estas instrucciones, el clero secular se mostraba más fuerte, adinerado y mejor preparado que al principio del siglo. Había podido asumir el liderazgo del programa evangelizador reemplazando a las autoridades civiles y a las órdenes religiosas, también había logrado aplicar legislación sistemática que regulaba y homogeneizaba la administración de las doctrinas. El programa de asentar comunidades indígenas en pueblos planeados (las llamadas "reducciones") estaba avanzando, se aceleró especialmente a partir de la década de 1590, y ofrecía ventajas concretas para la evangelización. Más aún, la Iglesia era capaz cada vez más de dotar a estas nuevas comunidades de personal bien entrenado, no solamente en su educación teológica sino en lenguas indígenas; y de implementar un programa sistemático de supervisión y visitas para vigilar la conducta de todos los doctrineros, fueran seculares o regulares. Las instrucciones de Torres, en otras palabras, no serían letra muerta. Pero en paralelo a este cambio institucional, había ocurrido también uno de carácter ideológico, el resultado de la llegada y recepción de las ideas y prioridades del catolicismo tridentino, que tuvo un impacto profundo sobre la evangelización de la población indígena del Nuevo Reino de Granada.

La coyuntura ideológica de las primeras décadas de la evangelización por un lado de la influencia del humanismo y de la Prerreforma española en la perspectiva de las autoridades, y por el otro de la caracterización que se llegó a tener de la población indígena- resultó en que la evangelización se limitara a la catequización, a la transmisión de las oraciones y principios básicos de la doctrina cristiana, pero con pocos resultados. Sin embargo el movimiento de renovación y reforma religiosa liderado por el Concilio de Trento llegó a ofrecer una alternativa que se puede vislumbrar en las instrucciones de Torres. En este periodo, el catolicismo de la práctica cotidiana, de los sacramentos, de las devociones populares, la participación y la disciplina social, llegó a verse como el método para lograr que los indios, como decía Clemente VIII, llegaran a ser por fin "del todo cristianos".

A pesar de la difícil llegada del clero secular al Nuevo Reino de Granada, y los esfuerzos de los arzobispos Juan de Los Barrios y especialmente Luis Zapata de Cárdenas por fortalecer y fomentar su desarrollo, algunas de sus políticas tuvieron consecuencias perdurables, como el nuevo énfasis que se hizo sobre la importancia de las lenguas indígenas en la evangelización (que seguiría tomando fuerza); o la ordenación masiva de clérigos seculares que 
acrecentó dramáticamente su número, aunque de manera muy controversial. Otras medidas fueron menos exitosas o sufrieron reveses. Algunas incluso fracasaron del todo, como el intento del arzobispo Zapata por establecer un seminario diocesano o celebrar un concilio provincial. En general, los esfuerzos de Zapata no lograron establecer una base institucional para la reforma de la Iglesia y de su programa evangelizador; gran parte del progreso logrado en su episcopado fue deshecho en los ocho años de sede vacante que siguieron a su muerte. De esta manera, cuando su sucesor Bartolomé Lobo Guerrero (arzobispo 1596-1607), se quejaba de muchos de los mismos problemas de los que se había quejado Zapata en 1573, no era del todo una exageración.

\section{LA PUJA POR EL LIDERAZGO DE LA IGLESIA}

Cuando Bartolomé Lobo Guerrero llegó a la ciudad de Santafé en marzo de 1599, estaba claro que reformar la Iglesia no iba a ser fácil. El nuevo Arzobispo le escribió al Rey en mayo para describir la situación que había encontrado y ya tenía claro que las órdenes religiosas presentarían problemas. Se había logrado progresar muy poco en la implementación de la legislación lingüística de 15741580, y muchos sacerdotes criollos y mestizos ordenados por Zapata estaban desempleados, habiendo sido despojados de sus doctrinas por los regulares y sus aliados (AGI SF 226, núm. 61, 1r). Las órdenes religiosas habían vuelto a su comportamiento problemático y su negativa a obedecer a las autoridades diocesanas -o incluso a cooperar con ellas-, estaba más arraigada que nunca. "Si yo en razón de hacer mi oficio procediese contra ellos por la mala administración del suyo en las doctrinas que están a su cargo", se quejaba el nuevo arzobispo, "nombrarían contra mi juez conservador y me descomulgarían" (2r), como ya lo habían hecho antes de su llegada con el cabildo de la catedral.

Estaba claro entonces, que la primera tarea que el nuevo arzobispo debería enfrentar sería la de restablecer el poder de las autoridades diocesanas sobre el gobierno de la Iglesia e imponer su control y jurisdicción sobre las órdenes religiosas. Para hacerlo, Lobo Guerrero necesitaría del apoyo de las autoridades civiles. Pero incluso en esto se enfrentaba a la oposición. El Arzobispo había llegado a la ciudad por Pamplona y Tunja, donde había sido recibido de manera respetuosa, incluso con entusiasmo, por las autoridades locales. Pero, como se quejó ante el rey desde su primera carta, el presidente de la Audiencia, Francisco de Sande, le había brindado una recepción helada (AGI SF 226, núm. 61, 1r). Esto era apenas una muestra de lo que le esperaba. 
Figura 1. Anónimo. (s. f.). Arzobispo Bartolomé Lobo Guerrero. En: José Restrepo Posada (1961-1971). Arquidiócesis de Bogotá. Bogotá: Ed. Lumen Kelly, vol. 1.

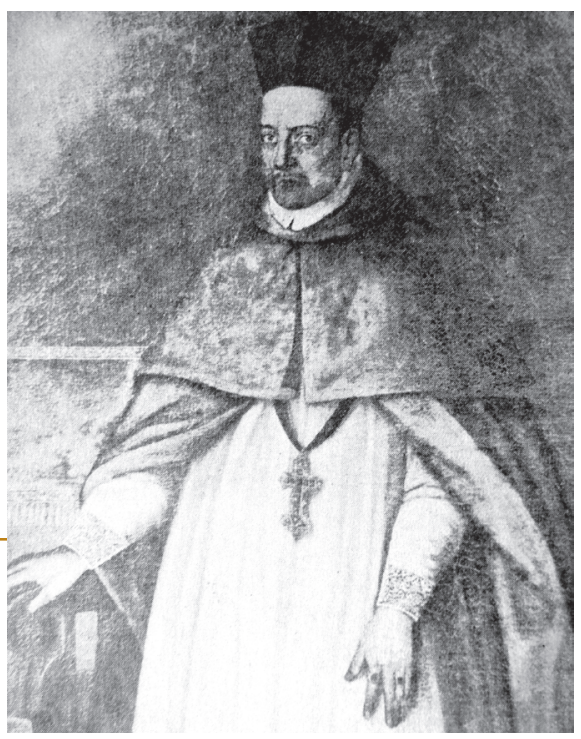

Durante su controversial episcopado, Zapata de Cárdenas había luchado por mantener el control sobre la Iglesia frente a la intervención de las autoridades civiles. Ahora, habían aprovechado el vacío de poder de la sede vacante para fortalecer su control sobre el gobierno de la Iglesia. Por ejemplo, fue precisamente durante la década de 1590 que la Audiencia comenzó a implementar con mayor vigor sus esfuerzos de reducción de la población indígena a pueblos planeados, bajo el liderazgo del poderoso oidor Martín Enríquez. Pero también habían empezado a tomarse varias de las funciones más importantes del obispo. Por ejemplo, durante una de sus visitas el oidor Miguel de Ibarra había encontrado a un doctrinero que estaba sobrecargado y "no podía cumplir con las doctrinas de sus pueblos por ser muchos los indios", y decidió dividir la doctrina en "seis o siete doctrinas" (3r). Tuvo la cortesía de informar al cabildo de la catedral, el cual gobernaba la Arquidiócesis durante sede vacante, pero hasta ahí estuvo dispuesto a permitirle a las autoridades diocesanas a que se involucraran y él mismo instaló frailes en las nuevas doctrinas, a pesar de las quejas vociferantes del cabildo, de sacerdotes seculares desempleados e incluso de los encomenderos de los pueblos, quienes ahora tendrían que ayudar a sostener las nuevas doctrinas (3r).

Este era apenas el comienzo. Dos semanas más tarde, en junio, Lobo Guerrero se quejó de que la Audiencia le había enviado alguna legislación relativa a la Iglesia que esperaban que implementara, "usurpa[ndo] la jurisdicción eclesiástica” y mostrando una completa indiferencia por las censuras 
del derecho canónico (AGI SF 226, núm. 64, 1r). Incluso en materias de ceremonia el presidente Sande y sus aliados parecían esforzarse por demostrar su desprecio por el arzobispo. Durante una misa, cuando a Lobo Guerrero le ofrecieron el beso de la paz antes que a él, Sande se negó a recibirlo por completo (AGI SF 226, núm. 64a, 1r).

Las autoridades seculares no fueron las únicas en tener que aguantar que las autoridades civiles interfirieran en sus asuntos. Cuando los franciscanos del Nuevo Reino se reunieron en 1599 para elegir un nuevo provincial, Sande intervino en las elecciones para asegurarse que su candidato fuera elegido. $Y$ "con amenazas, a unos que les había de embarcar y buscar sus vidas, a otros con promesas y que daría oficios de justicia a sus deudos y amigos", Sande "los compelió con violencia y fuerza" a que eligiesen a un tal fray Martín (AGI SF 226 núm. 65, 1r), que luego resultó ser su hermano (AGI SF 226, núm. 78, 2r). Como los mismos franciscanos se quejaron al rey, "[el Presidente] a los religiosos los desasosiega con sus libertades, teniendo poco respeto a sus prelados" (AGI SF 238, núm. 2, 1r). Estos conflictos iban más allá de lo exclusivamente jurisdiccional, de qué le correspondía a quién: era una problemática mucho más amplia y fundamental, una puja por el control y el liderazgo de la Iglesia. Y como si el ya antiguo conflicto entre seculares y regulares no fuera suficiente, ahora la $\mathrm{Au}$ diencia se había constituido en un tercer poder en asuntos eclesiásticos y estaba haciéndose sentir en un esfuerzo por subordinar a los otros dos bajo su control.

Los siguientes seis años del episcopado de Lobo Guerrero estarían marcados por el conflicto con las autoridades civiles; la mayoría de la correspondencia del Arzobispo con la corona en estos años consistió en quejas acerca de Sande, Enríquez y otros miembros del gobierno. Como lo describió en su carta de enero de 1600, eran "tantas exorbitancias que no tuvieron mayor principio las herejías de Alemania e Inglaterra" (AGI SF 226 núm. 68, 1r). Al escoger este lenguaje, Lobo Guerrero tenía la intención de escandalizar a la corona, pero aun así hay alguna sustancia en su preocupación por la hostilidad de las autoridades civiles hacia el clero: no, como decía, porque podría resultar en algún tipo de cisma o comportamiento herético, sino por un motivo más básico aún.

Como consecuencia de los excepcionales privilegios y poderes que tenía la corona sobre la Iglesia del Nuevo Mundo -el patronato real- era esencial que las autoridades civiles y eclesiásticas trabajaran juntas, no solo para reformar la Iglesia, sino incluso para su funcionamiento cotidiano. De esta manera, dicha falta de cooperación era el obstáculo más grande que el nuevo arzobispo tendría que superar. Aunque las autoridades civiles estaban implementando políticas que harían contribuciones muy importantes para la evangelización de la 
población indígena, como fue la creación de pueblos de indios; el problema era la duplicación. Ambas autoridades buscaron hacer cosas similares, y esta superposición creaba conflictos jurisdiccionales que frecuentemente dificultaban los esfuerzos de las dos, o hasta los hacían fracasar. Más aún, sus métodos y prioridades no siempre estuvieron en sintonía, en una situación que recuerda a los conflictos entre el arzobispo Zapata y las órdenes religiosas en el siglo XVI. La duplicación de funciones, en otras palabras, era enemiga del esfuerzo tridentino hacia la homogeneización y uniformidad en la disciplina y en la práctica.

Dicho argumento queda claro en un número de ejemplos concretos. Una fuente de tensión fue la decisión de la Audiencia de investigar cuestiones eclesiásticas en sus visitas civiles. Como Lobo Guerrero se quejó en mayo de 1599, la legislación de la corona mantenía "que cuando algún oidor hubiere de salir a visitar la tierra, lo haga saber al arzobispo para que envíe persona de su parte que asista con él y vea lo que debe remediar en los clérigos" (AGI SF 226 núm. 66, 1r). Este era el modelo de cooperación entre autoridades eclesiásticas y civiles que la corona había diseñado. Pero la Audiencia no estaba cumpliendo su función y estaba involucrándose en causas eclesiásticas sin molestarse en informar a las autoridades diocesanas.

Cuando Luis Enríquez visitó la doctrina de Suta y Monquirá, por ejemplo, le exigió al doctrinero que le entregara las llaves de la iglesia para poder hacer una inspección del edificio y sus ornamentos (AGI SF 226, núm. 69, 1r). Esta era una de las funciones centrales de la visita eclesiástica, un ejercicio que hacía visible la autoridad del obispo, y que consecuentemente estaba regida por un protocolo claro y una ceremonia determinada. El doctrinero se negó y la $\mathrm{Au}-$ diencia le ordenó a Lobo Guerrero que lo destituyera de la doctrina. "Conmigo", se quejaba luego el obispo, "no se comunicó nada más que encargarme que yo fuese ejecutor de lo que proveyeron” (AGI SF 226, núm. 69, 1v). Y el obispo no tenía mayor opción que cooperar, quejándose de que "ni hay jurisdicción eclesiástica ni se tiene respeto al sacerdocio" en el Nuevo Reino de Granada.

Mientras tanto, Lobo Guerrero estaba intentando llevar a cabo su propia visita de la Arquidiócesis, enviando sus representantes a las localidades, pero las autoridades civiles estaban socavando sus esfuerzos. Alonso Domínguez de Medellín, el corregidor de Tunja y un aliado cercano del oidor Enríquez, le declaró a las autoridades indígenas de la provincia que el visitador eclesiástico que Lobo Guerrero había enviado no tenía poder sobre ellos; que si trataba de castigarlos por idolatría, incesto, concubinato u otros pecados, "que se defendiesen" pues estos visitadores "no eran sus jueces ni podían castigarlos". Incluso, si un visitador tratara de capturar a alguien, "que no lo consintiesen, 
y que antes ellos se juntasen y amarrasen al dicho visitador y a su cura, y lo enviasen [...] a esta real Audiencia así amarrado y reprendido" (AGI SF 226, núm. 68i, 1r). Estas eran acusaciones serias y el Arzobispo llamó a varios testigos para comprobar su veracidad. La mayoría fueron sacerdotes y sus respuestas son algo predecibles. Pedro de Zea, un sacerdote de Tunja, dijo que había oído a los indios dando "castañetas de alegría" luego de oír las instrucciones de Domínguez, diciendo "que de ahí en adelante no había para que creer lo que el padre les mandaba y decía" (6v). El doctrinero de Samacá incluso propuso que algunos "le seguirán como los luteranos hicieron a Martín Lutero" (8r). Pero más allá de toda esta retórica, lo importante por resaltar es que esta rivalidad y duplicación de funciones solo podrían tener un impacto negativo en la evangelización. Estos ejemplos muestran que más allá de quejarse, el Arzobispo no podía hacer mucho al respecto.

Las cosas solo empeorarían. Pronto, el Arzobispo y la Audiencia se vieron involucrados en una disputa acerca de la práctica de los visitadores eclesiásticos de cobrar multas. Estos dineros se debían dividir entre los gastos de la visita y la construcción o mantenimiento de la doctrina en la que se cobraban, pero la Audiencia cuestionó su legalidad. El propio Arzobispo recibió una orden de la Audiencia al respecto cuando realizaba su visita en Mariquita, y varios agentes de la Audiencia le decomisaron los papeles de la visita y arrestaron a su notario. Frustrado, Lobo Guerrero no podía hacer más que quejarse al rey y tuvo que dejar de hacer su visita por completo (AGI SF 226, núm. 70, 1r). Cuando el Arzobispo citó a Domínguez de Medellín para que se explicara, la audiencia intervino para protegerlo (AGI SF 226, núm. 681, 1r). Incluso, otros testigos que habían dado testimonios al Arzobispo acerca del comportamiento de Enríquez y Domínguez, fueron rastreados y encarcelados por la Audiencia -incluidos los sacerdotes-, luego de que esta obtuvo la documentación del caso (AGI SF 226, núm. 74a). Lobo Guerrero volvió a intentar investigar las acusaciones que se hacían acerca de Enríquez y cuando se negó a entregarle los documentos que produjo a la Audiencia, Sande y sus hombres "le cercaron y cerraron las puertas de su casa, y se la quitaron violentamente con mucho alboroto de la gente" (AGI SF 226, núm. 78, 1v).

El presidente Sande murió en 1602, pero los problemas de Lobo Guerrero no se acabaron. Las órdenes religiosas seguían oponiéndose a los requerimientos de la legislación lingüística y el Arzobispo intentó resolver el problema ordenando que cada doctrinero apareciera ante él y el catedrático de la lengua general para ser examinados (AGI SF 226, núm. 87, 3v). Sin embargo, la Audiencia intervino una vez más y desplazó al Arzobispo a la fuerza, de tal forma que, 
como este se quejó en mayo de 1603, "en los exámenes que se han hecho ante los oidores han sido admitidos y aprobados muchos para el servicio de las doctrinas sin saber la lengua de los indios ni entenderla", mientras que los clérigos seculares doctos en lenguas indígenas permanecían desempleados (4r). Claro está que estas quejas del Arzobispo y sus agentes solo muestran un lado de la historia y probablemente exageran los excesos de las autoridades civiles. Fundamentalmente, el problema era que ambos, de cierto modo, tenían la razón.

El Arzobispo podía decir que la Audiencia intervenía "sin atender que el negocio era meramente eclesiástico" (4r), pero en realidad la distinción entre las jurisdicciones no siempre estaba clara. De todas formas, estas quejas son testimonio del terrible estado de las relaciones entre dos brazos del gobierno español que deberían haber estado colaborando para avanzar su proyecto compartido de evangelización, y de los problemas de Lobo Guerrero en su esfuerzo por establecer su liderazgo sobre la Arquidiócesis. En todo caso, las quejas de Lobo Guerrero no cayeron en oídos sordos y la corona respondió nominando un sucesor a Sande en 1605 que estuvo mucho más dispuesto a cooperar con las autoridades eclesiásticas, don Juan de Borja, a quien Lobo Guerrero elogiaba en enero de 1606 por "honra[r] y respeta[r] las cosas de la iglesia y sus ministros".

La figura del obispo fue un pilar central de la estrategia tridentina para reformar la Iglesia (Nalle, 1992, p. 51; Traslosheros, 2004, p. 37). Pero en el Nuevo Reino en esta época, había poco que el obispo pudiera hacer sin el apoyo y cooperación de la autoridad civil. Solo fue cuando cambió el gobierno que los planes que tenía Lobo Guerrero para la Arquidiócesis de Santafé pudieron empezar a ser implementados de verdad. Esto no quiere decir que de ahí en adelante las relaciones entre las autoridades civiles y eclesiásticas del Nuevo Reino de Granada hayan sido armónicas. De hecho, las relaciones entre el arzobispo Bernardino de Almansa (1631-1633) y el Marqués de Sofraga, el sucesor de Borja, fueron incluso en ocasiones peores que aquellas entre Lobo Guerrero y Sande 2 . Pero el clero secular del Nuevo Reino estaría en una posición distinta, más firme y las diferencias personales entre los dos tendrían un efecto más limitado sobre su funcionamiento.

Mientras que el arzobispo Zapata de Cárdenas había sido un reformador franciscano en Espańa y el Perú, utilizando los métodos disciplinarios existentes

2 Véase, por ejemplo, las quejas de Almansa del 24 de abril de 1632 y del 23 de agosto de 1633 (AGI SF 227, núm. 2 y núm. 14, respectivamente). Para una descripción sobre este asunto, véase Lucena, 1967, pp. 139-174. 
y la explotación al máximo de sus poderes como arzobispo -incluso de manera implacable, como en sus ordenaciones- para reformar la iglesia del Nuevo Reino, Lobo Guerrero tenía una trayectoria distinta, que lo llevó a considerar una manera de proceder diferente. Era doctor en derecho canónico y fue académico en la Universidad de Sevilla, donde llegó a ser rector de uno de sus colegios (González 2001, p. 15). En 1580 había sido enviado a México a servir como fiscal en la Inquisición, convirtiéndose en inquisidor en 1593, llegando a ser el oficial de más alto rango en la Inquisición mexicana hasta su nombramiento como arzobispo de Santafé en $1596^{3}$. Para ese entonces, ya había desarrollado lazos fuertes con la Compañía de Jesús y con su provincial en la Nueva España, Estéban Páez. De hecho, uno de sus primeras acciones como arzobispo, antes de partir para el Nuevo Reino, fue ordenar al sacerdocio al jesuita Francisco de Figueroa, a petición de Páez (Pacheco, 1975, p. 29).

En vez de partir para su nueva sede inmediatamente, Lobo Guerrero pasó un tiempo en México preparándose para su nueva misión. Parte de su estrategia consistió en convencer a Páez de que le permitiera llevar consigo a dos jesuitas. Y solo fue cuando esta petición fue aceptada por las autoridades de la Compañía en Roma, permitiéndole llevar al mismo Figueroa y a su compañero Alonso de Medrano, que Lobo Guerrero partió para Santafé, al final de abril de 1598, casi dos años después de su nombramiento (ARSI NR\&Q 14, 9r). En sus esfuerzos por reformar la Iglesia, Lobo Guerrero se apoyaría de manera fundamental en la Compañía de Jesús, como lo haría años más tarde en el Perú como arzobispo de Lima (Mills, 1997). Esta alianza pronto quedaría clara.

Una de las primeras señales de que la marea estaba cambiando en las relaciones entre las autoridades civiles y eclesiásticas del Nuevo Reino de Granada, fue una carta al Rey compuesta por el Arzobispo y el nuevo Presidente, que describía su visión conjunta para la reforma de la Iglesia del Nuevo Reino, el 17 de agosto de 1606 (AGI SF 226, núm. 103). Los problemas para ellos, eran el lento progreso de la evangelización, la persistencia de prácticas no cristianas, la corrupción del feligresado, la falta de educación y el inadecuado comportamiento del clero. No había mucho de nuevo en estas quejas. Pero ahora Lobo Guerrero y Borja tenían en mente una solución innovadora.

${ }^{3}$ Lobo Guerrero no fue la primera opción del rey. Primero había nominado al dominico Andrés de Caso, también inquisidor en México, en 1595. Caso había aceptado, pero luego cambió de opinión, quizás esperando una posición más alta. En 1603 fue nombrado obispo de León. Véase Pacheco, 1975, p. 29. 
Ellos propusieron convocar un sínodo, el primero desde 1556, y que en él "se recibiese el [Tercer] Concilio Provincial de Lima, aprobado por la Sede Apostólica, Su Majestad, y 23 años de experiencia", durante los cuales "se han mejorado mucho las provincias del Perú" (1r). Esta parecía ser la solución perfecta, pues les ahorraría tener que organizar un concilio provincial en Santafé por algunos años, iniciativa con la cual la corona estuvo de acuerdo (1v).

En lo que concernía a la evangelización de la población indígena, propusieron cuatro estrategias. Primero, siguiendo la sugerencia del Tercer Concilio Provincial de Lima (de ahora en adelante Lima III), propusieron congregar a todos "los sacerdotes de ídolos y hechiceros que acá llaman jeques o mohanes" y aislarlos en un edificio en Santafé donde pudieran vivir el resto de sus vidas (1v). Esto no fue radicalmente distinto a las políticas de sus predecesores, que se habían concentrado en las manifestaciones externas de la religiosidad indígena para erradicar lo que no consideraban compatible con el catolicismo. Pero había más. También recomendaron que los hijos de caciques fueran educados en una escuela a cargo de los jesuitas, "donde como nuevas plantas crezcan en fe y devoción cristiana, y olviden sus supersticiones" (1v), de tal forma que luego pudieran dar un buen ejemplo a sus súbditos y servir de aliados en el esfuerzo en contra de los elementos incompatibles con el régimen. Esto parecía estar inspirado por la estrategia jesuita de enfocarse en "aquellas personas y lugares que, siendo aprovechados, son causa que se extienda el bien a muchos otros que siguen su autoridad o se gobiernan por ellos" (Constituciones de la Compañía de Jesús, Cons. 7: 622 D).

El tercer punto fue más importante: un renovado énfasis en el uso de lenguas indígenas en la catequización (AGI SF 226, núm. 103, 1v). En 1605, Lobo Guerrero había entregado la doctrina de Cajicá a la Compañía de Jesús, para que la administraran y se familiarizaran con la lengua de aquellos indios. Al siguiente ańo estos jesuitas habían elaborado una traducción del Catecismo breve del III Concilio Provincial de Lima (AGI SF 226, núm. 101, 1v). Esta traducción fue criticada por otros lenguaraces (ARSI NR\&Q 12-I, 34r) y Lobo Guerrero y Borja decidieron que la mejor manera de proceder era congregar una junta de expertos para pulirla, un comité que incluía a las autoridades regulares, civiles y diocesanas, a varios encomenderos y a los intérpretes oficiales de la Audiencia (Borja describió el proceso en detalle en ARSI NR\&Q 14, 48v).

El resultado fue una traducción del texto al muisca de la región aledaña a la ciudad de Santafé, la llamada "lengua general" del Nuevo Reino de Granada, la cual Borja declaró oficial el 15 de agosto, dos días antes de enviar su carta 
al rey (ARSI NR\&Q 14, 49v) ${ }^{4}$. Claro está, esta traducción no resolvía el problema de la heterogeneidad lingüística del Nuevo Reino, pero en los próximos meses se diseñaron varias estrategias para superarlo, contando finalmente con la producción de traducciones del material a la lengua de cada doctrina (Cobo, 2014). Lo que sí había logrado esta reunión al crear un consenso que incluía a las autoridades regulares, seculares y civiles alrededor de una traducción, era finalmente eliminar la división que había surgido en el último cuarto del siglo XVI sobre la validez del uso de lenguas indígenas en la evangelización.

La cuarta propuesta de Lobo Guerrero y Borja también fue innovadora y además es reveladora del tamańo de sus ambiciones. Ambos pidieron a la corona que enviara la mayor cantidad posible de jesuitas, "los cuales se dividan de dos en dos, o de tres en tres, a pueblos de indios", donde pudieran llegar a dominar las lenguas indígenas y hacer "el oficio de curas" temporalmente, "hasta que los tengan [a los feligreses indígenas] bien instruidos en la fe y costumbres cristianas", cuando habrían de dejar el pueblo en manos de clérigos capaces y repetir el proceso en otro lugar (AGI SF 226, núm. 101, 2r). Los sacerdotes que los reemplazaran puede que "no sean suficientes para plantar de nuevo la fe", para implementar las reformas radicales que ellos tenían en mente, pero sí "para conservarla donde estuviere plantada" (2r). Más aun, "lo mismo se podrá hacer en las doctrinas de los frailes", de nuevo de manera temporal, "volviéndoselas en estando reformadas" (2r).

La propuesta, en otras palabras, era hacer una reforma general del programa evangelizador, reorientándolo según las prioridades y métodos de la Compañía de Jesús. La idea era ambiciosa y la corona se mostró cautelosa. Lobo Guerrero y Borja pidieron treinta jesuitas y que la mayoría fueran italianos (pues pensaban que ellos serían más hábiles con las lenguas indígenas), pero las notas marginales hechas por el Consejo de Indias en su petición redujeron este número a veinte, y que fuesen "españoles todos". Pero dio la luz verde, aunque advirtiendo a los reformadores que evitaran alienar "a las demás religiones y clérigos" (2r).

Para Lobo Guerrero y Borja, los problemas con el clero del Nuevo Reino eran principalmente su pobre comportamiento y preparación; ambos se podrían resolver con la educación. De hecho, la educación del clero ya era una prioridad para el Arzobispo, quien había restablecido el seminario diocesano unos meses atrás, en 1605. Ahora, el Arzobispo y el Presidente sugerían "de-

\footnotetext{
${ }^{4}$ Sobre la política lingüística de las autoridades eclesiásticas del Nuevo Reino de Granada, la heterogeneidad lingüística de los grupos muiscas, y la producción de estos textos, véase Cobo (2014).
} 
bajo de la disciplina y gobierno de los padres de la Compañía", para fomentar el desarrollo de una nueva generación de sacerdotes. Y en cuanto a la "falta de doctrina”, esta se podría remediar con el establecimiento de cátedras no solo para que los sacerdotes aprendieran las lenguas indígenas -como la cátedra que se había inaugurado en la década de 1580 - sino también de Latín, artes y teología, todas las cuales estaban ausentes en la región. Para este propósito, le pidieron a la corona 3.000 pesos para el establecimiento de un colegio jesuita en la ciudad (2r-2v). Esta importante carta, por lo tanto, esbozaba el programa de reforma institucional que las autoridades diocesanas de Santafé, con el apoyo del gobierno civil, implementarían en las décadas siguientes. Y el progreso se empezó a ver muy rápidamente.

\section{NueVA LEGISLACIÓN}

La piedra angular del programa de reforma religiosa implementado por Lobo Guerrero y Borja fue el sínodo diocesano que inauguraron el 21 de agosto de 1606, apenas cuatro días después de que compusieran su carta al rey ${ }^{5}$. Como era de esperarse, el sínodo reflejó las prioridades y preocupaciones de sus dos arquitectos principales, como las habían expresado en su carta. Pero también estuvo fuertemente influenciado por las prioridades de la Compañía de Jesús. Al fin y al cabo, había sido el jesuita Martín de Funes, el rector del colegio jesuita de Santafé, quien había traído las constituciones del III Concilio Provincial de Lima (AGI SF 226, núm. 127, 1r), las cuales el sínodo adaptó para la Arquidiócesis con "muy poco más que añadir" (Constituciones 1606, AHSB Libro 4, 2r). Tanto españoles como indígenas debían aprender las oraciones básicas, los sacramentos, los misterios básicos de la fe cristiana "y que todas las cosas que adoran las demás gentes no son Dios, mas son mentiras y demonios" (5r).

Para este propósito, el sínodo introdujo los textos principales del concilio limense para uso en la Arquidiócesis: el Catecismo mayor (3r), el Catecismo breve para Indios (reproducido 27v-31r), y el Confesionario (8r). Estos últimos dos textos debían ser traducidos a las lenguas indígenas y el Catecismo mayor

${ }^{5}$ Las Constituciones Sinodales se encuentran en un códice manuscrito del siglo XVII en el Libro 4 del AHSB, en cuarenta folios con su propia numeración. Este texto, que cito, también fue editado y publicado por Juan Manuel Pacheco (1975). Las constituciones sinodales fueron promulgadas el 2 de septiembre de 1606. 
adaptado en sermones para su uso entre la población indígena (4r). Cada domingo y festivo el párroco o doctrinero debía predicar una explicación en Español a los españoles y en lengua indígena en las doctrinas, y si era necesario, complementar con catequesis todos los martes y jueves para los adultos y todos los días para los nińos y los ancianos; lo mismo que para los españoles pero únicamente durante la cuaresma (4r). Hasta ahora, aparte de sistematizar el programa de instrucción religiosa e introducir importantes textos nuevos, el sínodo de 1606 no representó en términos prácticos un cambio radical a lo dispuesto por el sínodo de 1556. Pero las reformas no pararon ahí.

Las constituciones sinodales le dedicaron un capítulo entero a la reforma del clero. Siguiendo las instrucciones del Concilio Limense, prohibió que los sacerdotes se involucraran en negocios, so pena de excomunión (13v). No debían participar en las campañas de guerra ("pacificación”) contra pueblos indígenas, comedias u obras de teatro indecentes, o tener relaciones cercanas con mujeres (14r). No debían jugar a los dados, y si apostaban no debía ser por montos superiores a los dos pesos de oro de veinte quilates y jamás en tiendas o establecimientos de mala reputación (15r). También deberían disuadir a la población indígena de apostar; y bajo ninguna circunstancia debían jugar a las cartas con los caciques u otros indios (16r-17r). No debían cazar, ni criar aves ni perros de caza $(15 \mathrm{r}-15 \mathrm{v})$. Incluso se expidieron instrucciones detalladas acerca del vestido adecuado para los sacerdotes, el largo de sus barbas, el porte de armas y el tamańo de los cuellos (15r). Claro, nada de esto era nuevo. Eran los requerimientos de Trento y del III Concilio Provincial de Lima a la letra, pero era la primera legislación promulgada en la Arquidiócesis que cubría cuestiones tan amplias.

Muchos de sus puntos pueden parecer triviales, pero la legislación también trató cuestiones más fundamentales. El sínodo introdujo una prohibición clara a la práctica de algunos sacerdotes de no residir en las parroquias o beneficios que tenían. Incluso se les prohibió a los sacerdotes salir de la Arquidiócesis sin el permiso expreso del arzobispo (13v-14r). De hecho, no debían ausentarse de sus beneficios jamás, excepto en circunstancias excepcionales -para confesarse, o en urgencias- e incluso entonces tendrían que tener el permiso del obispo y dejar nombrado a un reemplazo (17r). En cuanto a la educación, los representantes del arzobispo en las provincias, sus vicarios, debían nombrar examinadores para evaluar la preparación y el comportamiento de los curas de sus jurisdicciones, prestando atención especial a su conocimiento de las ceremonias (12v).

De manera crucial, la legislación subordinó firmemente al clero regular que estaba involucrado en la administración de parroquias a la jurisdicción de las autoridades diocesanas. Tras años de conflictos jurisdiccionales que resultaron 
de la confusión que surgió acerca de la validez de los privilegios y exenciones de las órdenes religiosas con el Concilio de Trento, y de las libertades que habían disfrutado en los años de sede vacante y en el tiempo del conflicto entre Lobo Guerrero y Sande, el sínodo dejó la nueva posición clara. El texto dictaminaba que "a los tales religiosos", no se les permitiera que "digan misa, prediquen ni confiesen sin nuestra licencia” (18r). El sínodo les encargó a las autoridades regulares que cooperaran con el programa de reforma y aunque esto pareció engendrar una nueva era de antagonismo, dejaba en claro quién iba a tener el control sobre el programa de evangelización.

En cuanto a la población indígena, el sínodo ordenó a los sacerdotes que "tengan grande vigilancia y cuidado de enseñarles a vivir políticamente", como una precondición esencial a su desarrollo espiritual (25v). Legisló acerca de cómo debían acicalarse, vestirse, dormir en camas o hamacas (nunca en el suelo) y criar a sus hijos (26r). Los borrachos debían ser trasquilados y si eran importantes, incluso caciques, debían ser reportados a las autoridades civiles y sufrir un castigo ejemplar (17r). Era preciso enseñar a los indios los hábitos de una vida cristiana, las "cosas que a buenos cristianos pertenecen" (26r). A rezar al despertarse y antes de dormir, a visitar la iglesia para rezar antes de ir a trabajar. Debían tener imágenes y cruces en sus hogares, para sus devociones privadas. Y ser animados a tener rosarios y rezar con ellos (26r). Todo esto, claro, encima de su obligación de participar en los sacramentos de la Iglesia.

Los líderes indígenas debían servir como auxiliares de la evangelización, asegurándose no solo de que "jeques y santuarios en sus pueblos" fueran reportados a las autoridades y que prácticas no cristianas fueran eliminadas entre sus súbditos "so pena de que se les será quitado el cacicazgo y serán gravemente castigados" (27r), sino también de supervisar el comportamiento y la moral de sus subordinados. Bajo las mismas penas, evitar las borracheras, el concubinato, la superstición y otras ofensas. No organizar reuniones o celebraciones sin la presencia del cura, ni dejar que sus súbditos salieran de la parroquia sin informarle primero (27r). Es decir, la legislación ató de manera fundamental el oficio y la posición del cacique con la evangelización de la población bajo su jurisdicción.

$\mathrm{Al}$ igual que el sistema administrativo quiso volver a los líderes indígenas en caciques, en eslabones en la jerarquía del gobierno español (Gamboa, 2010), el sínodo buscó convertirlos en agentes de transformación religiosa. Y en un golpe final en contra de la configuración tradicional de estas comunidades, ordenó "que dentro de un mes deshagan los cercados" y que aceptaran las órdenes de reducción de la Audiencia, concluyendo finalmente el largo conflicto entre Lobo Guerrero y Enríquez (Constituciones 1606, AHSB Libro 4, 
27r). Al mismo tiempo, el sínodo instó a las autoridades civiles a terminar el programa de reducción y construcción de iglesias lo más pronto posible (11r).

Pasando a las mismas parroquias, el sínodo incluyó una lista clara de todos los ornamentos básicos que debía tener cada iglesia, desde el altar hasta las lámparas (13r). Reguló el empleo de seis agentes indígenas en las parroquias: seleccionados para servir en la iglesia y en el coro (11v), dando un buen ejemplo con su comportamiento además de servir de informantes al párroco $(23 \mathrm{v})$. Ellos debían estar exentos de obligaciones de tributo, entrenados y educados de manera obligatoria, para que la Iglesia del Nuevo Reino llegara al estándar de la del Perú (11v). De la misma manera, el sínodo requirió a todos los curas "así de indios como de españoles", que tuvieran "libros bastantes para escribir así los que se bautizan como los que se casan y confiesan” (5v). Las multas y penalidades a las que estarían sujetos los que no cumplieran cada requerimiento estaban detalladas en el texto en cada oportunidad, además de la aplicación de medidas disciplinarias a través de las visitas pastorales ${ }^{6}$. La ignorancia no serviría de excusa: todos los sacerdotes de la Arquidiócesis debían conseguir una copia de estas constituciones (3r). La legislación no sería letra muerta.

Las prioridades del sínodo eran claras. El clero debía quedar reformado, mejor educado y supervisado por las autoridades diocesanas. A la población indígena una vez más, era necesario enseñarle, no solo la doctrina cristiana, sino también cómo vivir en una manera compatible con la idea de civilización de los españoles. Las iglesias tenían que estar bien equipadas, tanto con ornamentos y objetos como con personal preparado. Y debían mantenerse registros documentales meticulosos. Todo esto respondía a la preocupación tridentina por la disciplina social. Nada era nuevo, excepto en este contexto. Más bien, en común con la tendencia más general de la Iglesia tridentina, la reforma dependía menos en la innovación o en la creación de nuevas instituciones o procedimientos y más en la correcta y sistemática aplicación de lo viejo (Lotz-Heumann, 2007, p. 250). Pero había, además, una tendencia paralela, que incluso ya se puede vislumbrar en el énfasis que hizo el sínodo en la importancia de introducir devociones y "cosas que a buenos cristianos

${ }^{6}$ Además de un capítulo entero dedicado a los visitadores y su comportamiento, que debían ser gobernados por las instrucciones al respecto del III Concilio Provincial de Lima (Constituciones 1606, AHSB Libro 4, 21v), el texto hizo referencia al control del cumplimiento y disciplina a través de visitadores en casi 20 ocasiones distintas $(5 \mathrm{r}, 6 \mathrm{v}, 7 \mathrm{r}, 10 \mathrm{v}, 12 \mathrm{r}, 14 \mathrm{r}$, $15 \mathrm{r}, 15 \mathrm{v}, 16 \mathrm{r}, 16 \mathrm{v}, 17 \mathrm{v}, 19 \mathrm{v}, 21 \mathrm{v}, 23 \mathrm{r}$ y $25 \mathrm{r}$ ). 
pertenecen" entre la población indígena y requerir la participación de algunos individuos escogidos en el funcionamiento cotidiano de la Iglesia. Introducir devociones privadas, imágenes y prácticas como el rosario era ahora una prioridad. Sí, la catequización seguía siendo la base de la conversión religiosa. Pero ahora no estaba sola. Estos hábitos cotidianos de la vida cristiana también eran claves al programa de conversión.

Este cambio de énfasis se puede ver más claramente en la actitud del sínodo hacia los sacramentos. Como antes, parte de su legislación se concentró en reforzar la aplicación de requerimientos ya establecidos: los padres indígenas, por ejemplo, debían llevar a bautizar a sus hijos dentro de ocho días de su nacimiento (Constituciones 1606, AHSB Libro 4, 6v). Registros meticulosos buscaban garantizar además que la población indígena cumpliera sus obligaciones sacramentales. Pero también hubo un cambio de distinto tipo. El sínodo hizo énfasis especial en la importancia de la confesión frecuente. La obligación anual de confesarse en cuaresma, introducida por el IV Concilio de Letrán, había estado en pie durante siglos. Pero por primera vez, con los avances hechos en requerir que los sacerdotes dominaran las lenguas indígenas y la introducción del confesionario del III Concilio Provincial de Lima, esto vino a ser posible en la práctica. El sínodo resaltó la obligación de los curas de "entender toda la conciencia de los dichos indios", por completo: la "falta de lengua, pereza o cansancio" no serían excusas admisibles (7v). Y más allá de su función sacramental, la confesión serviría una finalidad práctica, midiendo el progreso de la catequización de cada individuo. Los confesores debían "al principio de la confesión, preguntarles el credo, Padre nuestro y mandamientos, y por lo menos instruirles en los misterios principales de nuestra santa fe" (7v).

La confesión individual se había originado en Irlanda en el siglo VII y contrastaba con la práctica de confesión colectiva de la Iglesia temprana (Groupe de la Bussière, 1983, p. 17). La Iglesia carolingia había armonizado ambas prácticas, lidiando con los pecados públicos en público y con los privados en privado. El IV Concilio de Letrán introdujo luego el requerimiento de confesión individual anual y esta siguió coexistiendo con la penitencia pública medieval y la práctica de peregrinación penitencial (1983, p. 21). Pero estas dos últimas cayeron en desuso en el siglo XVI, cuando el sacramento fue transformado. Parafraseando a Henry Kamen, se puede decir que "posiblemente más que cualquier otro sacramento de la Iglesia, la confesión fue revolucionada en su naturaleza, estilo y contexto durante la Contrarreforma” (1993, 123). Mientras el sacramento en sí era una cuestión individual, cumplía una función social importante. Para Boer (2000, p. 119), los líderes de la Iglesia postridentina 
"adaptaron un procedimiento diseñado principalmente para la redención del alma individual para servir a lo que ellos consideraban era el bien común". Y esta fue una perspectiva compartida por la Compañía de Jesús en sus misiones en Europa y en otros lugares, pues para los jesuitas "la confesión no sólo era un medio para obtener perdón, sino un camino que llevaba a una nueva forma de vida”, una vida cristiana (Lualdi y Thayer, 2000, p. 8).

La confesión había sido un tema importante en la legislación anterior, pero ahora -con el énfasis en el mantenimiento de registros adecuados, entrenamiento lingüístico y su administración escrupulosa- se convirtió en una prioridad central. Esto quedó claro en uno de los requerimientos más llamativos del sínodo: "todas las licencias que tenemos dadas para confesar" quedaron revocadas "excepto las de los curas para con sus feligreses" (Constituciones 1606, AHSB Libro 4, 6v-7r). Es decir, la confesión sólo debía tener lugar estrictamente en el contexto de la parroquia. Y estos párrocos y doctrineros, debían presentarse a ser examinados en su habilidad para confesar, "y ninguno confesará sin nuestra licencia” (7r). El poder de oír confesiones y conferir la absolución, afirmaba el sínodo, provenía del ordinario. Y Lobo Guerrero, al examinar a todos los confesores en su habilidad y suficiencia, no solo se cercioraba de que se cumplieran sus requisitos sino que imponía su poder como ordinario.

En cuanto a la admisión de la población indígena a la eucaristía, que el sínodo de 1556 había prohibido terminantemente, los reformadores de 1606 hicieron clara su posición: era la práctica central de la Iglesia tridentina y la población indígena debía ser admitida. Claro está, esto no iba a ser un desorden. Se requería de permiso de las autoridades diocesanas, pues la Iglesia debía cerciorarse de que quienes recibieran el sacramento fueran idóneos y estuvieran preparados. Pero el sínodo no solo introdujo medidas para que la población indígena pudiera cumplir el requerimiento de la comunión anual, sino también tomar el sacramento en otros momentos del año. Más aún, específicamente requirió a los curas que administraran el viático "a los indios y esclavos, a la hora de la muerte", siempre y cuando estuvieran "bien dispuestos" y adecuadamente preparados $(9 \mathrm{v})$.

La participación frecuente en la comunión y confesión era uno de los distintivos de la concepción Jesuita de la misión, aunque seguía siendo controversial entre otros sectores de la Iglesia (O’Malley, 1993, p. 141; Châtellier, 1997, p. 11; Kamen, 1993, pp. 121, 123). Ahora se convertiría en un aspecto central de la evangelización del Nuevo Reino, un agente en la transformación de la vida religiosa de la población indígena. El sínodo no le estaba dando la espalda al énfasis que antes se había hecho en la catequesis. Es más, uno de los distintivos del 


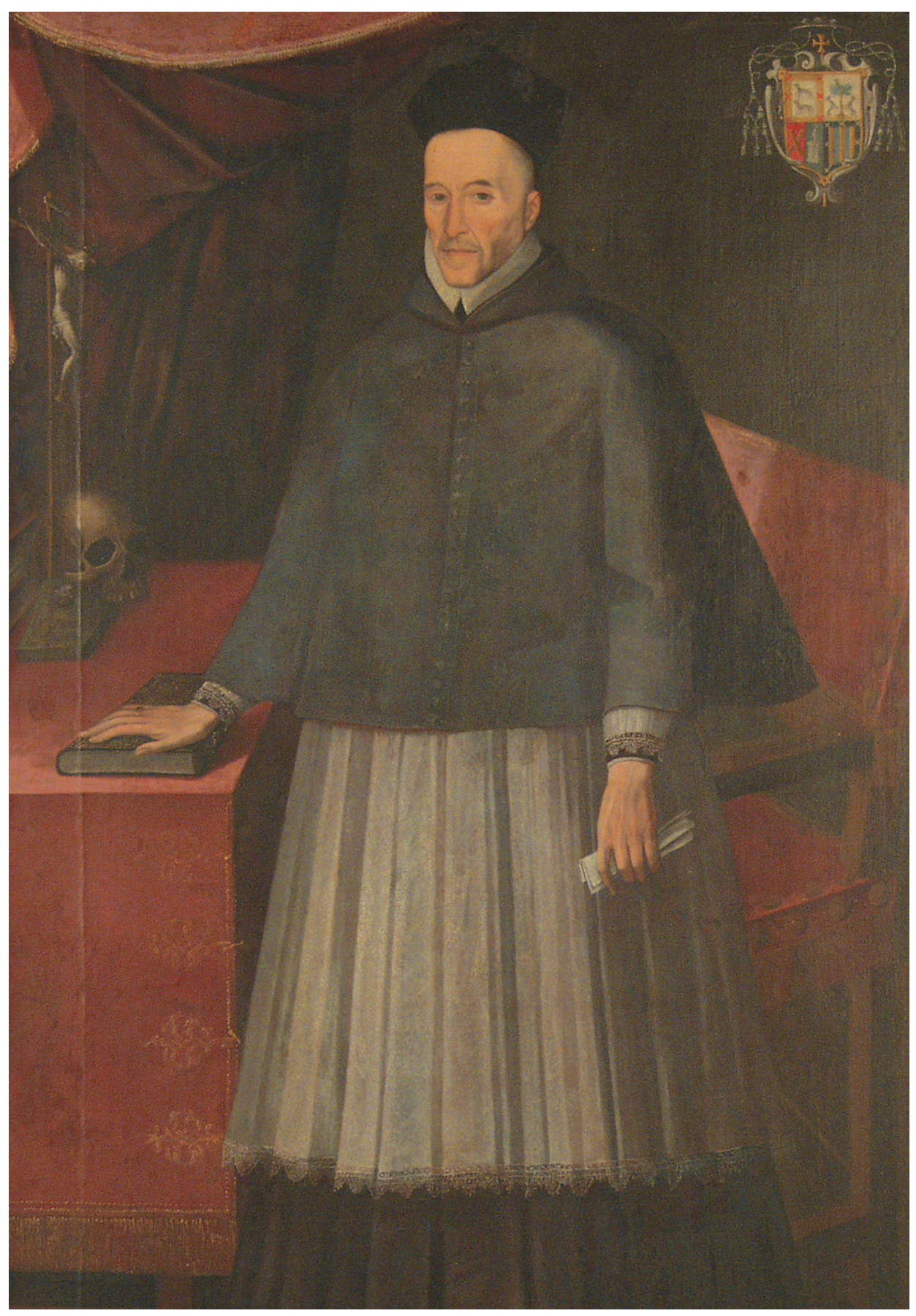

Figura 3. Gaspar de Figueroa. (Siglo XVII). Arzobispo Hernando Arias de Ugarte. Bogotá: Colección Museo Santa Clara. Número de registro. 03-1-043. Fotografía de Alberto Sánchez. 
catolicismo tridentino fue la renovada "obligación impuesta sobre cada creyente de conocer su religión [...] de ahora en adelante, para salvarse, había que tener conocimientos" (Châtellier, 1997, p. 13). Pero estos conocimientos debían incluir y ser complementados, con el comportamiento y la práctica cotidiana.

Claro está que el sínodo de 1606 no se implementó de la noche a la mañana. Desde 1608 Lobo Guerrero se quejaba de que los frailes eran lentos en obedecerlo (AGI SF 226, núm. 127, 1r). Pero la corona estaba dispuesta a contribuir a la reforma. Cuando se enteró de que estaban negándose a contribuir al mantenimiento del seminario, autorizó al Arzobispo a quitarles sus doctrinas si no cooperaban (AGI SF 226, 127b, 2r). Y cuando el Arzobispo se quejó de que no estaban siguiendo la legislación lingüística, les ordenó que la obedecieran (AGI SF 226, n. 127, 1v). Otros cambios se sintieron con mayor rapidez. En su misma carta de 1608, Lobo Guerrero informó al rey que ya había despojado de parroquias a tantos frailes incompetentes que no hablaban lenguas indígenas, que ya no quedaban sacerdotes seculares lenguaraces desempleados (AGI SF 226, 127, 1v).

La introducción de los textos y legislación del III Concilio Provincial de Lima había sido diseñada como una medida temporal, una respuesta realista dados los pocos recursos de la Iglesia y la urgencia de reformarla. Cuando el arzobispo Hernando Arias de Ugarte (1618-1625) llegó a Santafé en 1618, le reiteró al rey la necesidad de seguir utilizando estos textos, por lo menos por un tiempo adicional (AGI SF 226, núm. 142, 7r). Su petición fue aceptada en un breve de Paulo V de agosto de 1620, Exponi nobis nuper fecit, por cinco años (AGI SF 226, núm. 154a). Acabándose el plazo, Arias de Ugarte debidamente convocó el Primer Concilio Provincial de Santafé ${ }^{7}$ en junio de 1624, que se reunió el siguiente año (AGI SF 226, núm. 162, 1r). En ese momento, la diócesis de Cartagena estaba vacante, y envió un representante, como también lo hizo el obispo de Popayán que dijo estar demasiado enfermo para participar en persona. El obispo de Santa Marta sí se presentó (AGI SF 226, núm. 161, 1r). La situación contrasta de manera dramática con el fracasado intento del arzo-

${ }^{7}$ Una parte de las constituciones del Primer Concilio Provincial de Santafé fue editada y publicada por Restrepo (1964). El texto explicaba que la intención era publicar la primera edición completa pero esto nunca se terminó. El texto de las constituciones, que se creían perdidas, fue localizado durante la preparación de este volumen por los investigadores del Instituto de Estudios Socio-Históricos Fray Alonso de Zamora- IESHFAZ, de la Universidad Santo Tomás. Sobreviven en el ACCPC, en un códice del siglo XVIII que también incluye la legislación de los sínodos de 1556 y 1606. 
bispo Zapata de organizar un concilio provincial medio siglo atrás y reflejaba el fortalecimiento de la autoridad del arzobispo de Santafé sobre la Iglesia de la región. Una vez más, la base consistió en la legislación del III Concilio Provincial de Lima y también del III Concilio Provincial de México (AGI SF 226, núm. 161, 1r). La mayor innovación del concilio fue la producción de un material catequético propio a la Arquidiócesis. De resto, el contenido de sus constituciones más bien elaboró lo que ya se había establecido en el sínodo de 1606 y su énfasis en los sacramentos y el comportamiento. Por ejemplo, instaba a los doctrineros a instruirlos en el misterio de la eucaristía con frecuencia: "estimulen su deseo de semejante beneficio, exhórtenlos especialmente a detestar sus pecados y a hacer una confesión honesta" (ACCPC, Constituciones 1625, 25). Su mayor contribución, entonces, fue extender las reformas introducidas en la Arquidiócesis metropolitana en 1606 a las diócesis de Cartagena, Santa Marta y Popayán. En todo caso, esto solo es un lado de la historia.

\section{MANO DE OBRA Y EDUCACIÓN}

Los reformadores podían tener todo el entusiasmo que quisieran, pero como había descubierto el arzobispo Zapata en el siglo XVI, el recurso más básico para la evangelización del Nuevo Reino era la mano de obra clerical. Cuando Juan de Los Barrios llegó a la ciudad de Santafé, encontró apenas unos veinte franciscanos, unos pocos dominicos, y menos de veinte clérigos seculares en toda la Arquidiócesis. Cuando murió en 1569, había ordenado apenas a cuatro más (Lee, 1963, pp. 10 y 30). Pero la situación cambió en los siguientes ańos con la llegada de nuevos frailes y las ordenaciones del arzobispo Zapata (Cobo, 2012).

Los reportes de las autoridades eclesiásticas del Nuevo Reino ofrecen algunas cifras concretas. En mayo de 1609, el cabildo de la catedral de Santafé envió un reporte a la corona que describía el estado de la Iglesia en la Arquidiócesis, con información acerca del número de conventos masculinos, su afiliación y el número de frailes presente en cada uno (AGI SF 231, núm. 60 y 60a). Los dominicos tenían ocho conventos y 107 frailes, de los cuales 70 estaban activos en las provincias de Santafé y Tunja, aunque no se especificó cuántos estaban a cargo de doctrinas (AGI SF 231, núm. 60a, 1r). Los franciscanos tenían siete conventos y 73 frailes, de los cuales 60 correspondían a las provincias de Santafé y Tunja. Los Agustinos, por su parte, tenían seis conventos y 51 frailes, con 26 de ellos en las dos provincias mencionadas. 
De estos, nueve eran doctrineros. También tenían un convento de recoletos cerca de Villa de Leyva, con otros diez religiosos (1v). Once años después, en una carta de 1620, el arzobispo Arias de Ugarte reportó que los mendicantes tenían a su cargo 65 doctrinas de indios: los dominicos veintiocho, los franciscanos veinticuatro, los agustinos diez y los jesuitas tres (AGI SF 226, núm. 146, 1r). La situación era muy distinta a la de las más o menos tres docenas de frailes activos en la Arquidiócesis en la década de $1550^{7}$.

El clero secular también creció de manera sustancial. No existen cifras precisas, pero es posible hacer algunos cálculos. Barrios ordenó apenas a cuatro sacerdotes entre su llegada en 1553 y su muerte en 1569, cuando el total fue de alrededor de dos docenas. Pero Zapata de Cárdenas ordenó a por lo menos 124 sacerdotes en sus diecisiete años como arzobispo (Cobo, 2012). El crecimiento del clero continuó bajo sus sucesores y cuando Arias de Ugarte escribió al rey en 1620 , podía reportar que había 240 sacerdotes seculares: 160 con parroquias, doctrinas, sacristías y otros beneficios, y 60 desempleados (AGI SF 226, núm. 146, 1v). Ocho años después, el arzobispo Julián de Cortázar (16251630), quien llegó a Santafé en junio de 1627, reportó que el número de los desempleados había subido a 118, "los más hijos y nietos de conquistadores y graduados en la facultad de artes y teología, [...] que yo he ordenado estas órdenes" (AGI SF 245, s. n., 1628-06-24, 1r). En otra carta de 1628, Cortázar detalló a cada uno de los 118 desempleados, de los cuales 58 residían en la provincia de Santafé y 42 en la de Tunja -cifras que no incluían "los ordenantes que están estudiando latinidad y artes, que serán 300 poco más o menos” (AGI SF 245, sin número, expediente fechado 1628-01-15, 3v)-. Incluso si asumimos que el número de parroquias, doctrinas y otros beneficios eclesiásticos permaneció igual entre los reportes de Arias de Ugarte y Cortázar, el número total de sacerdotes seculares en la Arquidiócesis de Santafé en 1628 puede haber sido alrededor de 278: más de diez veces el número de 1569 y a punto de aumentar aún más con los 300 seminaristas que se estaban preparando.

El otro componente fundamental en la estrategia de reformar la Iglesia fue el restablecimiento del seminario diocesano. El arzobispo Zapata había fracasado en este proyecto y su seminario había cerrado en 1586 (AGI SF 226, núm. 57). El maestrescuela, Francisco de Porras Mejía, bajo cuya jurisdicción

\footnotetext{
${ }^{8}$ Aunque para poner estos números en una perspectiva más amplia, vale la pena resaltar que mientras en 1609 había 241 frailes en toda la Arquidiócesis de Santafé, en la década de 1590 había 500 frailes en la ciudad de Lima (Olaechea, 1995, p. 234).
} 
estuvo el seminario, pasó los ańos de la sede vacante buscando la manera de volverlo a abrir y creyó encontrarla con la llegada de la Compañía de Jesús (AGI SF 231, núm. 27). Lobo Guerrero estuvo de acuerdo y le pidió ayuda a la corona (AGI SF 226, núm. 61, 4v). Pero su conflicto con las autoridades civiles retrasó el proyecto hasta 1605, cuando finalmente se logró establecer con el apoyo de los jesuitas. Su propósito, como escribió el primer rector al rey en 1606, era el "total remedio del idiotismo y ruines costumbres que hay en el clero de este arzobispado, y que habrá curas idóneos para todo él, y se reformará" (AGI SF 242, sin número, fechada 1606-01-08).

Lobo Guerrero había donado una casa y algo de dinero para el seminario, luego el sínodo de 1606 ordenó que cada doctrinero contribuyera con ocho pesos (Constituciones 1606, AHSB Libro 4, 17r). En 1619 Arias de Ugarte dotó el seminario con unas nuevas constituciones para gobernarlo y trató de fortalecer su situación financiera requiriendo que todos los beneficiados de la Arquidiócesis, ahora excluyendo a los doctrineros que ya habían contribuido, pagaran el $2 \%$ de su capital y de sus rentas anuales. Lo mismo aplicaría a todas las capellanías fundadas desde 1605 (ASHB Caja 1, s. n., Constituciones, 11r). Claro, no todos pagaron el dinero que debían y en 1639 el arzobispo Cristóbal de Torres legisló una vez más para obligar a los réprobos a pagar, pero el seminario había quedado establecido y prosperó (AHSB Caja 1, 160r). Más aun, cuando el papa Gregorio XV promulgó In Supereminenti en 1621, dándole el poder a los colegios jesuitas del Nuevo Mundo de conferir títulos, el colegio de Santafé empezó a suplementar al seminario diocesano con la educación del clero, ofreciendo entrenamiento en teología moral, filosofía, retórica, gramática y artes (ARSI NR\&Q 12-I, 192r), y como es bien conocido en los siguientes años se fundaron o formalizaron otras instituciones educativas.

\section{MÉTOdos tridentinOS PARA EL GOBIERNO DE LA IGLESIA}

Al mismo tiempo, los mecanismos disciplinarios de la Arquidiócesis se volvieron cada vez más sofisticados y sistemáticos. Esto se puede ver claramente en lo que fue el principal instrumento de control y reforma a disposición de las autoridades diocesanas: la visita pastoral. Zapata realizó algunas, por ejemplo en la década de 1570 cuando quiso investigar reportes de "idolatría" indígena. Lobo Guerrero realizó visitas más extensas, pero tuvo que abandonarlas durante su conflicto con el presidente Sande. Más adelante las reanudó después de que el régimen cambiara, aunque ahora a través de representantes. Una serie 


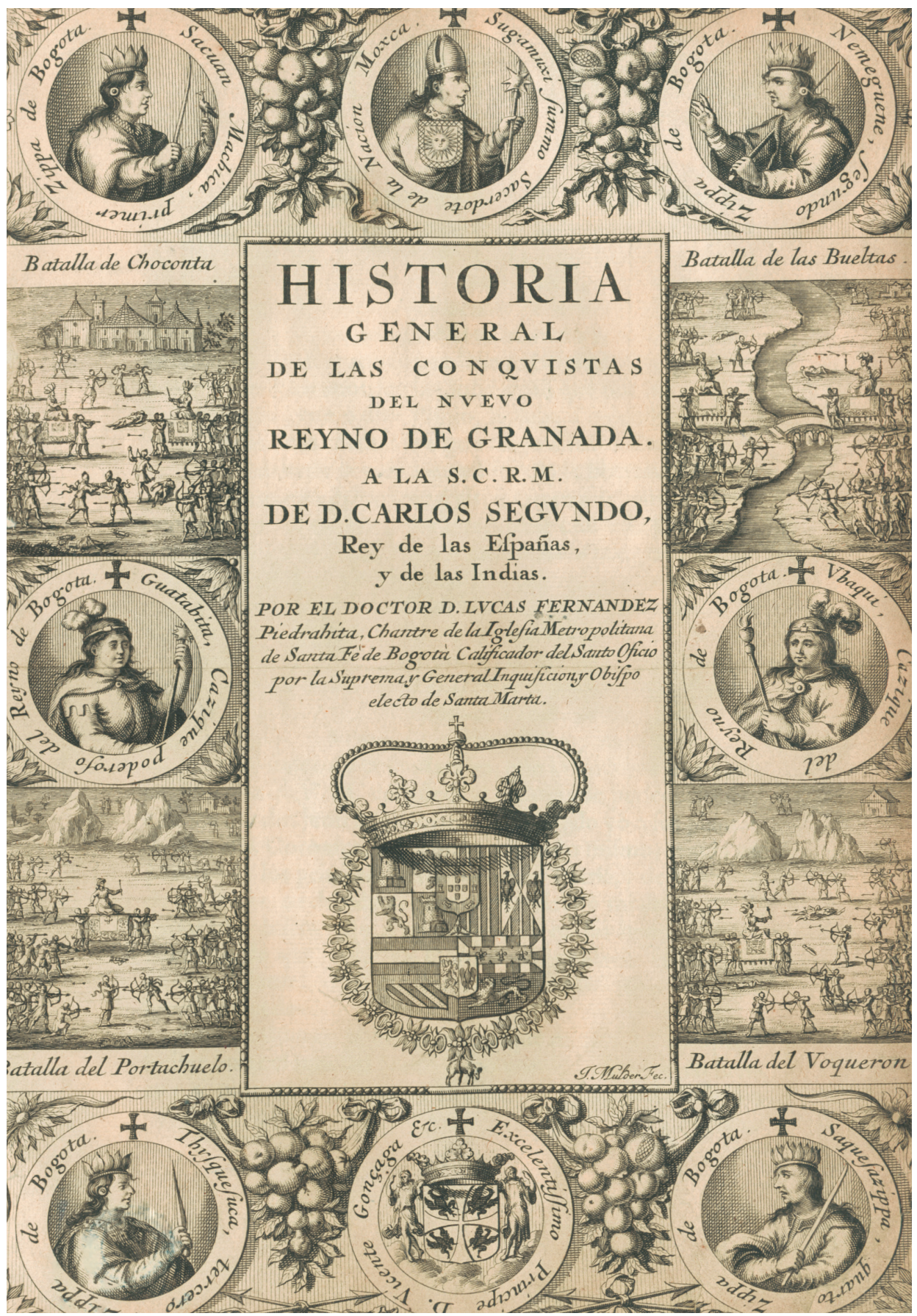

Figura 4. Lucas Fernández de Piedrahita. (1688). Historia general de las conquistas del Nuevo Reyno de Granada. Bogotá: Biblioteca Nacional de Colombia. Número topográfico: RN. 12. 
de instrucciones para visitadores de 1608 sobrevive, y nos permite vislumbrar sus prioridades (AGI SF 226, núm. 123b). Los visitadores debían examinar el interior de las iglesias, sus pilas bautismales, los registros parroquiales y otros objetos. También tenían la obligación de inspeccionar las cuentas de la doctrina y oír las quejas que tuviera el feligresado acerca del doctrinero (1r). Si era necesario, dichos visitadores tenían que hacerle un examen al párroco o doctrinero de su habilidad para oír confesiones y expedir las licencias correspondientes (2r).

El sucesor de Lobo Guerrero, Pedro Ordóńez y Flórez (1610-1614), parece no haber alcanzado a realizar visitas pastorales antes de su muerte en 1614, apenas quince meses después de haber llegado a Santafé. Pero Hernando Arias de Ugarte, su sucesor, realizó las visitas pastorales más exhaustivas de cualquier arzobispo de Santafé hasta entonces y en todo el siglo XVII. Estas se realizaron en tres rondas, empezando en mayo de 1619. La primera cubrió gran parte de la provincia de Santafé (Ospina, 2004, pp. 32-71), y la segunda, la de Tunja y parte de los Llanos Orientales (AGI SF 226, núm. 155, 1v; Ospina, 2004, pp. 76-97). Finalmente a partir de septiembre de 1621, la tercera lo volvió a llevar a la provincia de Tunja y luego a la de Pamplona, regresando a Santafé en julio o agosto de 1623 (Ospina, 2004, pp. 99-168). Mucha de la documentación de las visitas no ha sobrevivido, incluso una parte importante se perdió en la visita misma, cuando el arzobispo casi se ahogó (Pacheco, 1975, p. 75).

Otras fuentes son más detalladas. Aparte de la documentación que cargaba el visitador, también se dejaba un testimonio de cada visita en los libros de registro de las parroquias visitadas - los libros de bautismo, de defunciones, de cuentas o de bienes - puesto que estos registros siempre eran examinados. Relativamente pocos libros de este tipo han sobrevivido o han podido encontrarse en la actualidad. De los registros de Oicatá, podemos ver que entre 1608 y 1649 , las visitas pastorales se volvieron frecuentes y cada vez más sistemáticas. Este pueblo queda muy cerca a Tunja, por lo que la frecuencia de las visitas probablemente fue más alta que en lugares más remotos, siendo visitada en estos ańos la doctrina por lo menos nueve veces por las autoridades diocesanas (AGN PB Oicatá, Rollo 1, 86r, 14r, 92v, 94v, 48r, 107r, 115r, 122r y 131r).

Las visitas eran ocasiones propicias para que las autoridades diocesanas comprobaran que sus directivas se estuvieran cumpliendo y para investigar quejas y corregir problemas. Pero eran más que un mecanismo disciplinario: eran un instrumento de gobierno, un canal a través del cual las autoridades podían avanzar su reforma de la Iglesia. Este capítulo empezó con la legislación del arzobispo Torres acerca de la admisión de la población indígena a la comunión, resaltando cómo sus instrucciones dejaban claro 


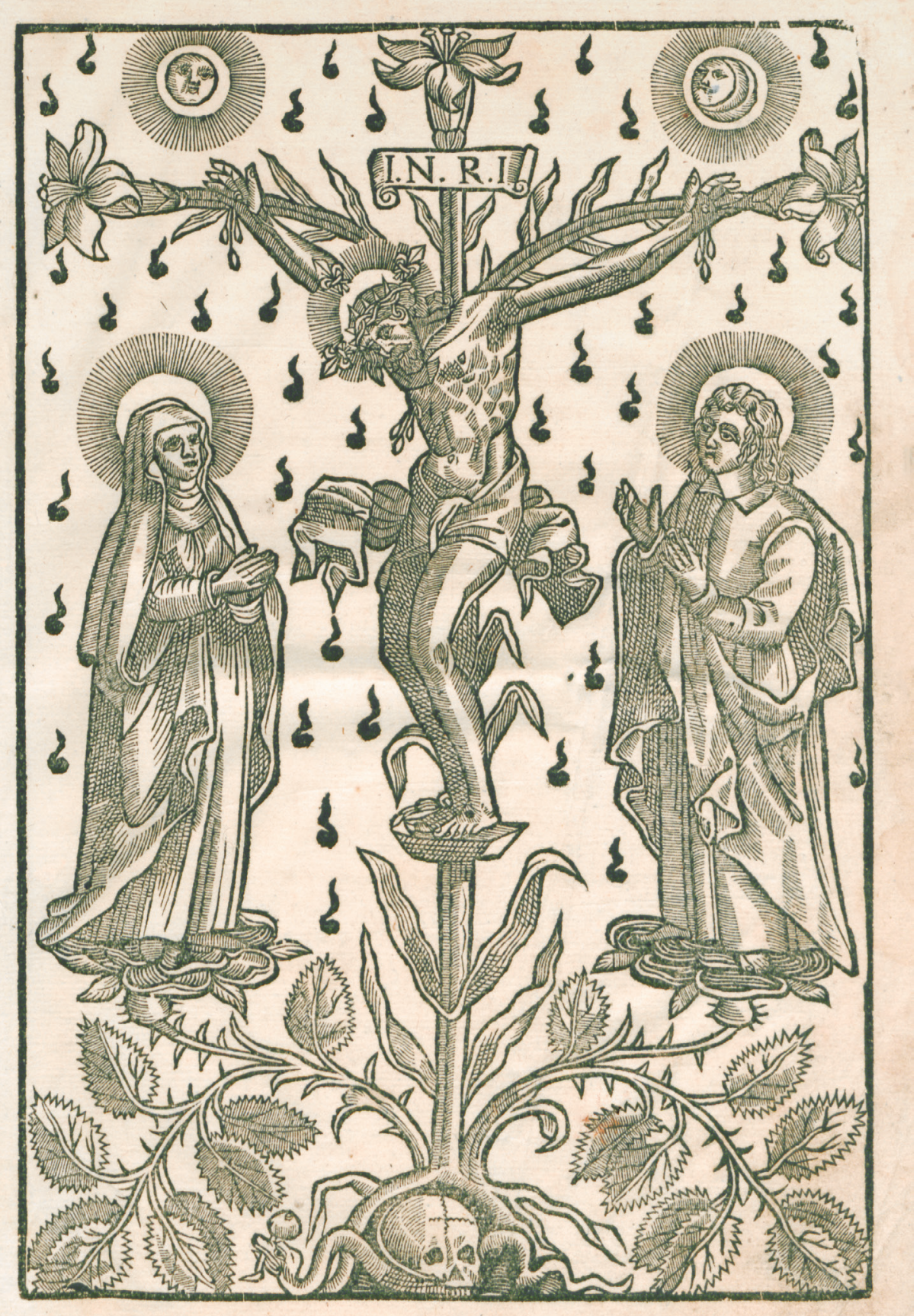

Figura 5. Pedro de Ribadeneyra. (1688). Flos Sanctorum o libro de las vidas de los santos. Barcelona: Editado en la casa de Vicente Suria. Bogotá: Biblioteca Nacional de Colombia. Número topográfico: RG. 1526. p. 9. 
que iba a utilizar las visitas pastorales para cerciorarse de que fueran obedecidas las nuevas directivas. Esta no fue la única oportunidad en la que de introdujo legislación de este tipo. Cuando Torres visitó Oicatá personalmente en marzo de 1640, le ordenó a su escribano que copiara una serie de instrucciones directamente en el libro de la parroquia.

La legislación estaba empapada del nuevo énfasis tridentino en la práctica cotidiana del catolicismo. Primero, Torres ordenó que no se hiciera ningún voto nuevo a ningún santo en la parroquia sin la aprobación de las autoridades diocesanas (AGN PB Oicatá, Rollo 1, 115v). Esto era para cerciorarse que todas las celebraciones se pudieran realizar de manera apropiada y sugiere que este tipo de devociones estaban proliferando, incluso de manera algo desorganizada, en las doctrinas de la Arquidiócesis en este periodo. Otras secciones requerían al doctrinero que vigilara la conducta de sus feligreses, por ejemplo la manera de vestir de las mujeres del pueblo o el comportamiento sexual. Las instrucciones incluían directivas precisas para preparar a los feligreses para los sacramentos de la penitencia y la eucaristía (AGN PB Oicatá, Rollo 1, 116r).

Lo más impactante fue quizás la instrucción para que el doctrinero "cada cuatro meses visite las casas de sus feligreses, y les haga que por lo menos tengan una cruz y una imagen" en sus hogares (115v). Los que no la tuvieran serían multados dos reales, que se destinarían a comprar los objetos exigidos. Torres, siendo un dominico, favorecía una práctica devocional por encima de las demás: "Por cuanto el santísimo rosario es único y singular presidio para extirpar errores contra la fe, y plantar virtudes en los corazones humanos", le ordenó a todos los doctrineros que enseñaran a rezar el rosario al feligresado y además que "procuren tener cofradía de Nuestra Señora del Rosario" en su parroquia, que organizara asimismo procesiones el primer domingo de cada mes (116v).

Por otra parte, estas instrucciones también son reveladoras de las limitaciones de la Iglesia del Nuevo Reino de Granada, de su condición de periferia. Torres tuvo que usar visitas pastorales para promulgar su legislación y sus instrucciones, para cerciorarse de que llegaran a las localidades de una manera confiable. El Nuevo Reino de Granada no tenía imprenta y lo que vemos aquí es una cultura manuscrita coexistiendo con la cultura de imprenta de la época: la circulación de textos provenientes del exterior, impresos como los materiales para la formación del clero, o los manuales que debían tener los doctrineros en sus parroquias, al lado de instrucciones manuscritas de las autoridades diocesanas y de traducciones manuscritas de textos esenciales. Mucho había cambiado en medio siglo, pero muchas cosas estaban aún lejos de ser ideales. 


\section{CONCLUSIÓN}

Las instrucciones del arzobispo Torres que se encuentran en los registros de Oicatá son un testimonio impactante de la significativa transformación que había experimentado la Iglesia del Nuevo Reino de Granada en la primera mitad del siglo XVII, al igual que de sus limitaciones. En un nivel básico, el hecho de que un arzobispo de Santafé estuviera en condiciones de llevar a cabo una visita pastoral sin obstáculos, en lo que se había convertido en un aspecto rutinario del gobierno diocesano, representaba un cambio importante del caos del principio del siglo. El poder del arzobispo sobre el gobierno de la Iglesia se había consolidado y los mecanismos disciplinarios que ofrecía la reforma tridentina habían sido adoptados y eran utilizados sistemáticamente. Torres también estaba visitando una arquidiócesis con un personal eclesiástico, tanto regular como secular, más abundante que nunca antes, sacerdotes mejor educados y entrenados que sus predecesores, incluso de tan solo una generación atrás. Había mucho por vigilar, claro, y parte del propósito de la visita era investigar quejas acerca de los doctrineros y ofensas que hubieran cometido, pero ya se había logrado construir un marco disciplinario para hacerlo posible.

De manera crucial, la transformación de la Iglesia del Nuevo Reino de Granada no había sido solo institucional, una cuestión de mejorar el entrenamiento y disciplina del clero, o de promulgar legislación comprensiva y textos catequéticos. Había sido también una transformación ideológica, un movimiento hacia las prioridades del catolicismo tridentino, en el cual los sacramentos, la disciplina social y las devociones cotidianas llegaron a estar en el centro del programa evangelizador. Claro está, esto apenas ha sido un examen superficial de los profundos cambios que transformaron a la sociedad y la Iglesia del Nuevo Reino en estos ańos y uno que se centra en la perspectiva de las autoridades. Falta mucho por explorar y quedan muchas preguntas por responder. 


\section{REFERENCIAS}

Archivo Capitular, Catedral Primada de Colombia (ACCPC): Constituciones. Archivo General de la Nación (AGN): Parroquias Boyacá (PB) Oicatá, Rollo 1.

Archivo Histórico, Colegio de San Bartolomé, Bogotá (AHSB): Caja 1, Libro 4.

Archivo General de Indias, Sevilla (AGI): Santafé (SF) 226, 227, 231, 238, 242, 245.

Archivum Romanum Societatis Iesu, Roma (ARSI): Provincia Novi Rengi et Quitensis (NR\&Q) 12-I, 14.

Boer, Wieste de (2000). The politics of the soul: confession in Counter-Reformation Milan. En K. J. Lualdi y A. T. Thayer, Penitence in the age of Reformations. Edited by Katharine Jackson Lualdi and Anne T Thayer. Aldershot, Reino Unido: Ashgate.

Châtellier, L. (1997). The religion of the poor: Rural missions in Europe and the formation of modern catholicism, c.1500-c.1800. Cambridge, Reino Unido: Cambridge University Press.

Cobo, J. F. (2012). Mestizos heraldos de Dios: la ordenación de sacerdotes descendientes de españoles e indígenas en el Nuevo Reino de Granada y la racialización de la diferencia, 1573-1590. Bogotá: Instituto Colombiano de Antropología e Historia.

Cobo, J. F. (2014). Colonialism in the periphery: Spanish linguistic policy in New Granada, c. 1574-1625. Colonial Latin American Review (en imprenta).

Constituciones de la Compañia de Jesús. (1993). Santander, España: Editorial Sal Terrae.

Gamboa, J. A. (2010). El cacicazgo muisca en los años posteriores a la conquista: del sihipkua al cacique colonial. Bogotá: Instituto Colombiano de Antropología e Historia.

González, G. (2001). Teatro eclesiástico de la primitiva iglesia de las indias occidentales, vidas de sus arzobispos y obispos, y cosas memorables de sus sedes. León: Universidad de León.

Groupe de la Bussière. (1983). Pratiques de la confession. Des pères du désert à vatican II. Quinze études d'histoire. París: Cerf.

Kamen, H. (1993). The phoenix and the flame: Catalonia and the counter reformation. New Haven: Yale University Press.

Lee, A. (1963). Clero indígena en el Arzobispado de Santafé en el Siglo XVI. Boletin de Historia y Antigüedades, 50 (579-581), 3-86. 
Lotz-Heumann, U. (2007). Imposing church and social discipline. En R. P. Hsia (Ed.). Reform and expansion, 1500-1660 (pp. 244-260). Cambridge, Reino Unido: Cambridge University Press.

Lualdi, K. J. y Thayer, A. T. (Eds). (2000). Introduction. En Penitence in the age of Reformations. Aldershot, Reino Unido: Ashgate.

Lucena, M. (1967). Historia Extensa de Colombia vol. III. ii: Presidentes de capa y espada (1628-1654). Bogotá: Academia Colombiana de Historia.

Mills, K. (1997). Idolatry and its enemies: Colonial andean religion and extirpation, 1640-1750. Chichester: Princeton University Press.

Nalle, S. T. (1992). God in la Mancha: religious reform and the people of Cuenca, 1500-1650. Baltimore: Johns Hopkins University Press.

Olaechea, J. B. (1995). Las instituciones religiosas de Indias y los mestizos. Cuadernos de Investigación Histórica, 16, 233-248.

O’Malley, J. W. (1993). The first jesuits. Cambridge, Estados Unidos: Harvard University Press.

Ospina, P. A. (2004). Hernando Arias de Ugarte (1561-1638): El criollo arzobispo de las tres sedes sudamericanas (Excerpta ex dissertatione ad Doctoratum In Facultate Historiae Ecclesiasticae Pontificiae Universitatis Gregorianae). Roma: Pontificia Universitas Gregoriana.

Pacheco, J. M. (1975). Historia Extensa de Colombia vol. XIII. ii: La consolidación de la iglesia, siglo XVII. Bogotá: Academia Colombiana de Historia.

Restrepo, J. (1964). El Sínodo Provincial del señor Arias de Ugarte (1625). Ecclesiastica Xaveriana, 14, 158-200.

Traslosheros, J. E. (2004). Iglesia, justicia y sociedad en la Nueva España: la audiencia del arzobispado de México, 1528-1668. México D.F.: Editorial Porrúa; Universidad Iberoamericana. 